\title{
E-modul berbasis Android sebagai pendukung pembelajaran daring dan upaya untuk meningkatkan hasil belajar peserta didik
}

\author{
Dewi Masruroh, Yuli Agustina* \\ Universitas Negeri Malang, Jl. Semarang No. 5 Malang, Jawa Timur, Indonesia \\ *Penulis korespondensi, Surel: yuli.agustina.fe@um.ac.id
}

Paper received: 7-6-2021; revised: 21-6-2021; accepted: 28-6-2021

\begin{abstract}
Abstrak
Saat ini dunia pendidikan menjadi salah satu sektor yang terdampak akibat adanya wabah Covid-19. Hal ini mengakibatkan kegiatan belajar mengajar dilaksanakan secara daring dengan memanfaatkan media elektronik salah satunya smartphone android. E-modul berbasis Android berbantuan software Flip PDF Professional merupakan bahan ajar digital yang tepat untuk mempermudah guru dalam menyampaikan materi pelajaran secara daring. Tujuan penelitian dan pengembangan ini, yaitu : 1) Menghasilkan E-modul berbasis Android, 2) Mengetahui kelayakan kegunaan E-modul berbasis Android, dan 3) Mengetahui perbedaan hasil belajar peserta didik. Rancangan penelitian ini menerapkan metode Research and Development oleh Borg \& Gall yang telah dimodifikasi. Teknik analisis data menggunakan uji validitas dan uji independent sample t-test. Hasil yang diperoleh dalam penelitian dan pengembangan ini menunjukkan bahwa E-modul berbasis Android memiliki tingkat kelayakan dengan kategori sangat valid dan sangat layak oleh ahli media, ahli materi dan enam peserta didik pada uji coba terbatas serta terbukti terdapat perbedaan rata-rata hasil belajar pada aspek kognitif dan psikomotorik yang signifikan pada uji coba kelompok besar dimana rata-rata hasil belajar kelas eksperimen lebih tinggi daripada kelas kontrol.
\end{abstract}

Kata kunci: penelitian dan pengembangan; e-modul; android; flip pdf professional; hasil belajar.

\section{Pendahuluan}

Pendidikan memegang peranan yang sangat penting dalam berbagai bidang kehidupan bermasyarakat dan juga bernegara. Semakin baik kualitas pendidikan akan sangat berpengaruh terhadap terciptanya kualitas sumber daya manusia yang unggul dan berkarakter. Melalui pendidikan akan melahirkan generasi muda yang menjadi agen perubahan untuk kemajuan suatu bangsa. Suprianto, et al., (2019) menyatakan pendidikan adalah sesuatu yang selalu melekat dengan kehidupan manusia, menjadi suatu budaya manusia yang dinamis dan penuh perkembangan yang mana prosesnya dipersiapkan agar manusia dapat menghadapi tantangan dunia di masa depan.

Dilema yang terjadi dalam dunia pendidikan saat ini yaitu dunia pendidikan menjadi salah satu sektor yang terdampak akibat adanya wabah Covid-19. Menanggapi peristiwa ini, para pemerhati pendidikan merancang berbagai strategi pelaksanaan pembelajaran yaitu dengan menerapkan PJJ (Pembelajaran Jarak Jauh) dan WFH (Work from Home). Hal ini mengakibatkan para pendidik dan peserta didik melaksanakan kegiatan belajar mengajar secara daring (dalam jaringan) dengan memanfaatkan kemajuan teknologi.

Pelaksanaan proses pembelajaran dikatakan berhasil apabila terdapat perubahan hasil belajar yang diperoleh peserta didik baik dalam aspek kognitif, afektif maupun dalam aspek psikomotorik. Purwanto (2011:44-45) mengatakan bahwa hasil belajar dapat dijelaskan dengan memahami dua kata yang membentuknya, yaitu "hasil" dan "belajar". Hasil menunjukkan pada suatu perolehan akibat dilakukannya suatu aktivitas atau proses yang 
mengakibatkan berubahnya input secara fungsional, sedangkan belajar dilakukan untuk mengusahakan adanya perubahan perilaku pada individu yang belajar. Sehingga dapat disimpulkan bahwa hasil belajar merupakan meningkatnya perubahan kemampuan, kompetensi dan keterampilan yang diperoleh oleh peserta didik setelah mengikuti proses belajar mengajar.

Dalam proses kegiatan belajar mengajar terdapat tiga konstituen utama yaitu guru, peserta didik dan sumber belajar (Ismiarti \& Nikmah, 2021). Sumber belajar yang baik adalah sumber belajar yang dapat memotivasi dan membawa peserta didik untuk mencapai tujuan pembelajaran yang diinginkan. Sanjaya (2011:228) mendefinisikan sumber belajar sebagai segala sesuatu yang ada disekitar lingkungan kegiatan belajar yang secara fungsional dapat digunakan untuk membantu optimalisasi hasil belajar. Sejalan dengan berkembangnya kemajuan teknologi informasi dan komunikasi, kini hadir sumber belajar digital yang dapat dimanfaatkan peserta didik untuk menunjang kegiatan pembelajaran daring sehingga kegiatan belajar mengajar tidak terbatas pada ruang kelas saja. Sumber belajar tersebut adalah $E$-modul. Fitryani \& Hunaepi (2016) mendefinisikan E-modul sebagai sarana pembelajaran yang berisi materi, metode batasan-batasan, serta cara mengevaluasinya yang dirancang dalam sistem elektronik untuk mencapai tujuan pembelajaran yang diharapkan. Selain itu Wijayanti, dkk (2016) mengatakan bahwa $E$-modul merupakan seperangkat bahan ajar digital atau non cetak yang disusun secara sistematis yang digunakan untuk keperluan belajar mandiri sehingga menuntut peserta didik untuk belajar memecahkan masalah dengan caranya sendiri. E-modul dapat menjadikan kegiatan pembelajaran menjadi lebih interaktif karena di dalam penyajiannya dapat disisipkan berupa animasi, gambar, video, maupun audio.

Dalam pelaksanaan pembelajaran daring saat ini, smartphone android menjadi media utama dalam menunjang kegiatan pembelajaran. Dalam penelitian yang dilakukan oleh Purnamasari, dkk (2016) mengatakan android merupakan suatu sistem operasi untuk telepon seluler (handphone) yang berbasis Linux. Penggunaan android dalam proses belajar mengajar diyakini dapat membawa banyak manfaat antara lain: peserta didik dapat belajar multi sumber (dengan koneksi jaringan internet), kegiatan pembelajaran dapat dilaksanakan dimanapun dan kapanpun tidak hanya terbatas di dalam ruang kelas saja, memberikan peluang bagi guru untuk mengembangkan teknik pembelajaran berbasis digital sehingga dapat memperoleh hasil belajar peserta didik yang maksimal.

Flip PDF professional merupakan salah satu software aplikasi yang dapat dimanfaatkan untuk mendukung pembuatan E-modul. Flip PDF Professional ini juga dilengkapi berbagai fiture multimedia seperti gambar,video, audio, dan juga animasi flash. Hasil akhir dari software ini lebih mudah untuk dioperasikan di PC dan mobile device yang sudah banyak dimiliki oleh peserta didik. Dalam penelitian yang dilakukan oleh (Arsal, dkk., 2019) menjelaskan bahwa bahan ajar yang dikembangkan dengan memanfaatkan software Flip PDF Professional dapat di publish secara online maupun offline sehingga memudahkan peserta didik untuk belajar mandiri. Di dalam Flip PDF Professional kegiatan evaluasi pembelajaran atau latihan soal dapat menampilkan feedback yang dapat menunjukkan jawaban benar atau salah dan skor yang bisa diketahui secara langsung.

Penelitian ini dirasa penting untuk dilakukan mengingat hasil penelitian yang telah dilakukan (Ahmar \& Rahman, 2017) yang menunjukkan hasil bahwa bahan ajar berbasis Android efektif digunakan untuk kegiatan pembelajaran dan peserta didik lebih cepat 
memahami materi pembelajaran. Penelitian lain yang juga relevan dilakukan oleh (Nurdiana, Sutarman, \& Widjianto, 2019) yang memperoleh hasil bahwa E-modul berbasis android yang dikembangkan dinyatakan layak untuk kegiatan pembelajaran suhu dan kalor dan dinyatakan menarik oleh peserta didik sehingga efektif digunakan untuk kegiatan pembelajaran secara mandiri dan efektif meningkatkan pemahaman peserta didik. Terdapat beberapa perbedaan antara penelitian dan pengembangan yang dilakukan oleh peneliti dengan penelitian sebelumnya. Perbedaan tersebut yaitu terletak pada perbedaan: 1) subjek uji coba, 2) mata pelajaran yang dikembangkan, 3) software yang digunakan untuk membuat E-modul, 4) tampilan dan penyajian $E$-modul, 5) kapasitas ruang penyimpanan $E$-modul yang rendah.

\section{Metode}

Rancangan penelitian ini menerapkan metode Research and Development oleh Borg \& Gall (dalam Sugiyono, 2017) yang telah dimodifikasi. Sehingga dari 10 tahapan penelitian, peneliti hanya melaksanakan 8 tahap prosedur penelitian. Metode pengembangan ini dipilih karena alur pengembangannya yang jelas serta mudah untuk diterapkan di dalam penelitian pendidikan dalam mengembangkan suatu produk. Adapun 8 tahapan langkah penelitian adalah sebagai berikut: (1) Potensi dan Masalah (2) Pengumpulan Data (3) Desain Produk (4) Validasi Desain (5) Revisi Desain (6) Uji Coba Produk (7) Revisi Produk (8) Uji Coba Pemakaian.

Pada penelitian ini Desain Produk yang dikembangkan akan diuji cobakan kepada ahli media dan ahli materi untuk mengetahui kelayakan media dan isi materi yang tersaji di dalam E-modul berbasis Android, setelah mendapat hasil pada angket penilaian, produk akan direvisi berdasarkan kritik dan saran dari ahli materi maupun ahli media. Setelah produk telah diperbaiki, langkah selanjutnya akan diuji cobakan kepada 6 peserta didik pada uji coba terbatas. Setelah memperoleh hasil validasi dari peserta didik, produk akan direvisi sesuai kritik dan saran yang terdapat pada lembar angket. Kemudian produk akan diuji cobakan kepada kelompok besar di kelas eksperimen dan kelas kontrol untuk mengetahui perbedaan hasil belajar peserta didik.

Data yang dihasilkan dalam penelitian dan pengembangan ini berupa data kualitatif dan data kuantitatif. Data kualitatif diperoleh dari kritik, saran dan komentar oleh validator ahli media, validator ahli materi serta pengguna (uji coba kelompok kecil) yang digunakan untuk perbaikan produk, sedangkan data kuantitatif diperoleh melalui perhitungan skor pada lembar validasi yang diberikan kepada validator ahli media dan ahli materi serta subjek uji coba (pengguna) E-modul.

Teknik analisis data yang digunakan dalam penelitian ini yaitu: uji validitas dan uji independent sample $t$-test. Validitas merupakan suatu ukuran yang menunjukkan pada suatu tingkatan kevalidan terhadap instrumen yang digunakan. untuk menghitung persentase skor secara keseluruhan item pada lembar validasi ahli materi, ahli media maupun lembar validasi uji coba terbatas maka harus menggunakan rumus sebagai berikut (Akbar, 2017:83).

Keterangan:

$$
\begin{aligned}
& V-a h=\frac{T s e}{T s h} \times 100 \% \\
& V-a u=\frac{T s e}{T s h} \times 100 \%
\end{aligned}
$$

$\mathrm{V}$-ah $=$ Validasi ahli

$\mathrm{V}$-au $=$ Validasi audiens/pengguna 
$\mathrm{T}_{\mathrm{se}} \quad=$ Jumlah skor empirik yang dicapai

$\mathrm{T}_{\mathrm{sh}} \quad=$ Jumlah skor yang diharapkan

$100 \%=$ Konstanta

Setelah diperoleh hasil analisis dengan menggunakan rumus di atas, maka akan diketahui kesimpulan tentang kelayakan yang didasarkan pada penggunaan skala Likert dengan kriteria validasi adalah sebagai berikut.

Tabel 1. Kriteria Validasi

\begin{tabular}{|c|c|c|}
\hline No. & Kriteria Validitas & Tingkat Validitas \\
\hline 1. & $81,00 \%-100,00 \%$ & $\begin{array}{l}\text { Sangat valid, sangat efektif, sangat tuntas (dapat digunakan } \\
\text { tanpa revisi) }\end{array}$ \\
\hline 2. & $61,00 \%-80,00 \%$ & $\begin{array}{l}\text { Cukup valid, cukup efektif, cukup tuntas (dapat digunakan } \\
\text { namun perlu revisi) }\end{array}$ \\
\hline 3. & $41,00 \%-60,00 \%$ & $\begin{array}{l}\text { Kurang valid, kurang efektif, atau kurang tuntas (disarankan } \\
\text { tidak dipergunakan karena perlu direvisi besar) }\end{array}$ \\
\hline 4. & $21,00 \%-40,00 \%$ & Tidak valid, tidak efektif, tidak tuntas (tidak boleh digunakan) \\
\hline 5. & $00,00 \%-20,00 \%$ & $\begin{array}{l}\text { Sangat tidak valid, sangat tidak efektif, sangat tidak tuntas } \\
\text { (tidak dapat digunakan). }\end{array}$ \\
\hline
\end{tabular}

(Sumber: Akbar, 2017:82)

Teknik analisis data selanjutnya yaitu uji independent sample t-test. Uji Independent Sample T-Test merupakan uji hipotesis yang digunakan untuk mengetahui perbedaan hasil belajar yang diperoleh peserta didik pada kelas eksperimen yang menggunakan E-Modul berbasis Android dengan hasil belajar peserta didik pada kelas kontrol yang tidak menggunakan E-Modul berbasis Android dalam kegiatan pembelajaran. Data yang digunakan pada uji ini diperoleh dari data nilai hasil posttest aspek kognitif dan psikomotorik pada kelas eksperimen dan kelas kontrol. Perolehan data tersebut akan dianalisis menggunakan uji Independent Samples T-Test berbantuan program IBM SPSS Statistics v.23.

\section{Hasil dan Pembahasan}

Dalam penelitian dan pengembangan ini menghasilkan produk berupa $E$-modul berbasis Android pada Mata pelajaran Administrasi Umum untuk semester genap kelas X OTKP. E-modul yang dikembangkan memiliki kapasitas penyimpanan yang rendah yaitu 8,5 MB dan dapat diakses secara online melalui smartphone dengan sistem operasi android. Berikut merupakan beberapa tampilan awal yang disajikan di dalam E-modul berbasis Android. 


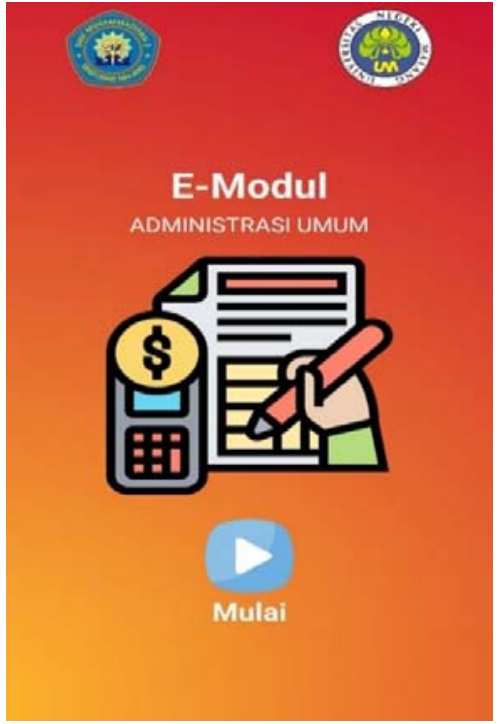

Gambar 1. Tampilan Awal $E$ modul

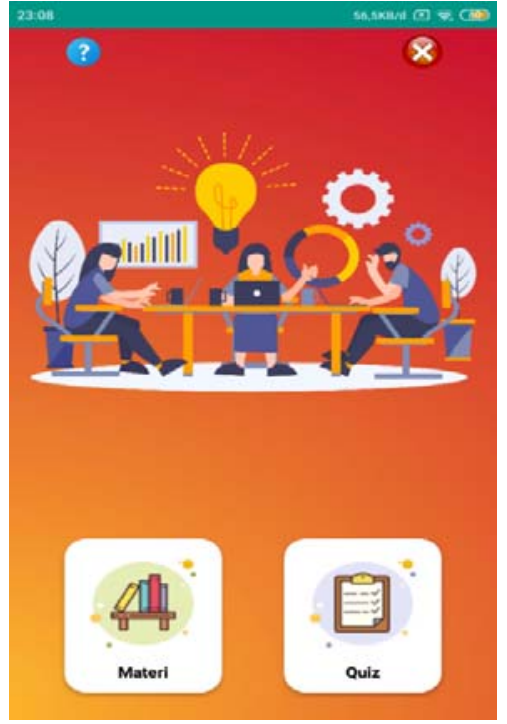

Gambar 2. Tampilan Menu $E$ modul

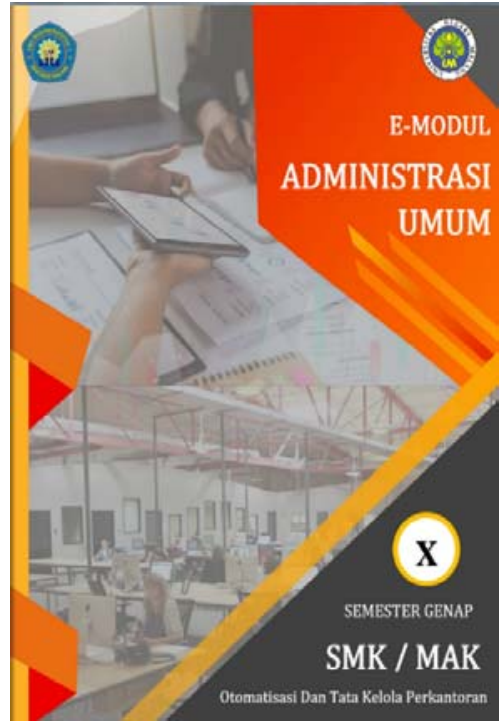

Gambar 3. Cover Depan $E$ -

Berikut merupakan tampilan E-modul berbasis Android pada bagian inti yaitu pada bagian kegiatan pembelajaran yang disajikan secara menarik serta dilengkapi dengan video pembelajaran.

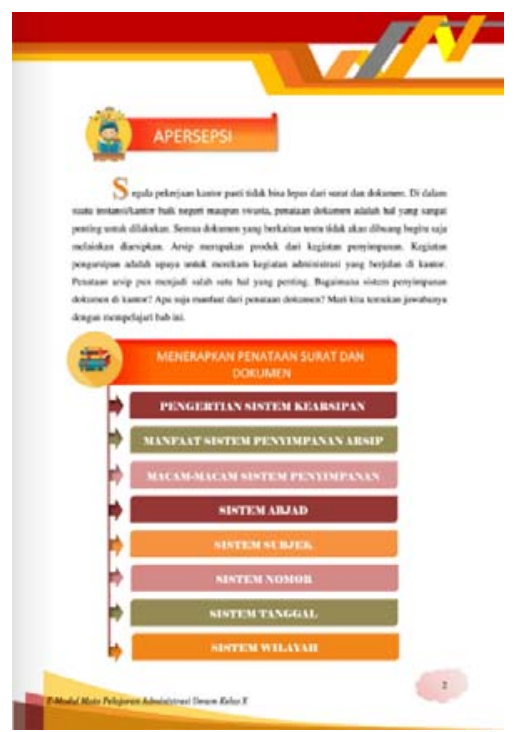

Gambar 4. Tampilan Apersepsi dan Peta Konsep Materi

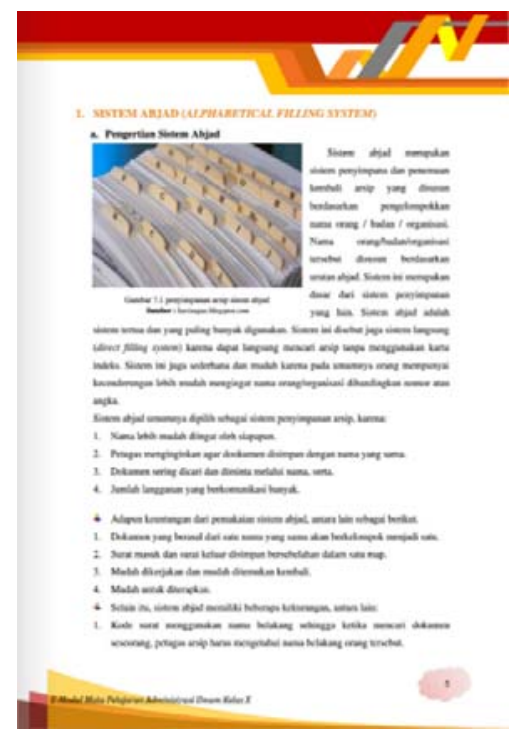

Gambar 5. Tampilan Materi dalam E-modul
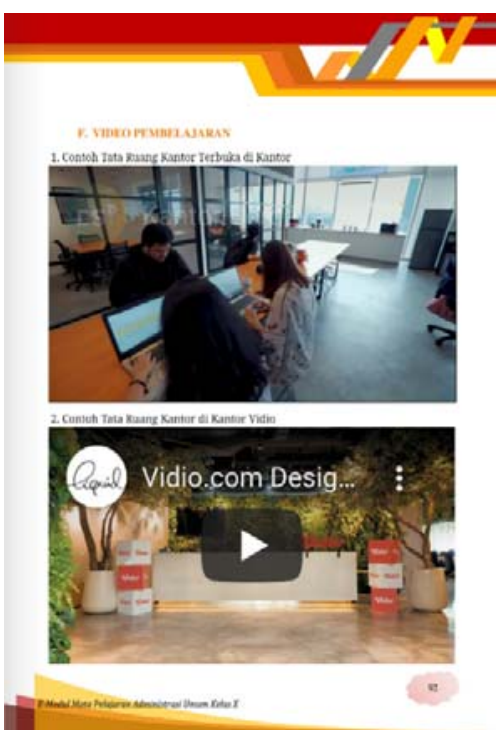

Gambar 6. Tampilan Video Pembelajaran

E-modul berbasis Android yang dikembangkan telah divalidasi oleh ahli media dan ahli materi serta peserta didik dalam uji coba terbatas, berdasarkan analisis hasil pada angket penilaian, hasil validasi ahli media memperoleh rata-rata skor sebesar 99,05\% dengan kategori sangat valid dan layak, hasil validasi ahli materi E-modul berbasis Android memperoleh skor persentase sebesar $96,47 \%$ dan dinyatakan sangat valid dan layak, sedangkan perolehan hasil uji coba terbatas pada peserta didik memperoleh skor sebesar 93,75\% dengan kategori sangat 
valid dan layak. Sehingga dari hasil perhitungan keseluruhan validasi dapat diperoleh rata-rata skor persentase sebesar $96,42 \%$ dengan kategori sangat valid dan layak digunakan untuk menunjang kegiatan pembelajaran daring maupun luring mata pelajaran Administrasi Umum di SMK Muhammadiyah 3 Singosari.

Selanjutnya yaitu uji independent sample t-test yang bertujuan untuk mengetahui perbedaan hasil belajar peserta didik. Pengukuran hasil belajar pada penelitian ini terdiri dari aspek kognitif dan psikomotorik.

\subsection{Aspek Kognitif}

Hasil belajar aspek kognitif dilihat dari perolehan hasil posttest pilihan ganda. Sebelum melakukan uji t, data hasil belajar peserta didik pada aspek kognitif dan aspek psikomotorik harus melalui uji normalitas data untuk mengetahui apakah data tersebut merupakan data yang berdistribusi normal atau tidak. Berikut merupakan uji normalitas data untuk aspek kognitif.

Tabel 2. Hasil Tes Normalitas Aspek Kognitif

\begin{tabular}{lllllll}
\hline \multicolumn{7}{c}{ Tests of Normality } \\
\hline & \multicolumn{3}{l}{ Kolmogorov-Smirnov } \\
\cline { 2 - 7 } & Statistic & $\mathrm{df}$ & Sig. & Statistic & $\mathrm{df}$ & Sig. \\
Eksperimen & .148 & 22 & $.200^{*}$ & .922 & 22 & .082 \\
Kontrol & .171 & 22 & .096 & .927 & 22 & .107 \\
\hline
\end{tabular}

(Sumber : Data Uji Normalitas)

Pada Tabel 2 diatas menunjukkan bahwa hasil uji normalitas data aspek kognitif pada kelas eksperimen sebesar 0,200 (sig.>0,05) dan pada kelas kontrol sebesar 0,96 (sig.>0,05), hal ini memberikan gambaran bahwa kedua kelompok data berdistribusi normal. Selanjutnya yaitu akan dilakukan Uji Independent Sample T-Test untuk mengetahui perbedaan rata-rata hasil belajar kognitif pada kelas eksperimen dan kelas kontrol.hasil uji Independent Sample TTest aspek kognitif dapat dilihat pada Tabel 3 berikut ini.

Tabel 3. Hasil Group Statistics Aspek Kognitif

\begin{tabular}{|c|c|c|c|c|c|}
\hline \multicolumn{6}{|c|}{ Group Statistics } \\
\hline \multirow{3}{*}{ Hasil Belajar } & Kelas & $\mathbf{N}$ & Mean & Std. Deviation & $\begin{array}{c}\text { Std. Error } \\
\text { Mean }\end{array}$ \\
\hline & Eksperimen & 23 & 80.4348 & 6.55623 & 1.36707 \\
\hline & Kontrol & 22 & 72.2727 & 8.55337 & 1.82359 \\
\hline
\end{tabular}

(Sumber : Data Hasil Uji Independent Sample T-Test Hasil Belajar Aspek Kognitif, 2021)

Berdasarkan data hasil group statistics pada aspek kognitif dari kelas eksperimen sejumlah 23 peserta didik dan kelas kontrol sejumlah 22 peserta didik yang mengikuti posttest diperoleh rata-rata hasil belajar pada kelas eksperimen sebesar 80,43 sedangkan rata-rata hasil belajar pada kelas kontrol sebesar 72,27. Nilai sig. (2-tailed) adalah 0,001<0,05 yang artinya terdapat perbedaan yang signifikan (nyata) rata-rata hasil belajar untuk ranah kognitif pada kelas eksperimen dan kelas kontrol. 


\subsection{Aspek Psikomotorik}

Hasil belajar aspek psikomotorik dilihat dari perolehan hasil praktik penyusunan surat dan dokumen. Berikut merupakan hasil uji normalitas data aspek psikomotorik.

Tabel 4. Hasil Tes Normalitas Aspek Psikomotorik

\begin{tabular}{lllllll}
\hline \multirow{7}{*}{ Kolmogorov-Smirnov } & \multicolumn{5}{l}{ Shapiro-Wilk } \\
\cline { 2 - 7 } Eksperimen & Statistic & $\mathrm{df}$ & Sig. & Statistic & $\mathrm{df}$ & Sig. \\
\cline { 2 - 7 } Kontrol & .169 & 22 & .101 & .899 & 22 & .029 \\
\hline & .175 & 22 & .077 & .887 & 22 & .017 \\
\hline
\end{tabular}

(Sumber : Data Uji Normalitas)

Pada Tabel 4 diatas menunjukkan bahwa hasil uji normalitas data aspek psikomotorik pada kelas eksperimen sebesar 0,101 (sig.>0,05) dan pada kelas kontrol sebesar 0,77 (sig.>0,05), hal ini memberikan gambaran bahwa kedua kelompok data berdistribusi normal. Selanjutnya yaitu akan dilakukan Uji Independent Sample T-Test untuk mengetahui perbedaan rata-rata hasil belajar kognitif pada kelas eksperimen dan kelas kontrol.hasil uji Independent Sample T-Test aspek kognitif dapat dilihat pada Tabel 5 berikut ini.

Tabel 5. Hasil Group Statistics Aspek Psikomotorik

\begin{tabular}{llllll}
\hline & \multicolumn{5}{c}{ Group Statistics } \\
\cline { 2 - 6 } Hasil & Kelas & N & Mean & Std. Deviation & Std. Error Mean \\
\cline { 2 - 6 } Belajar & Eksperimen & 23 & 85.0000 & 6.90849 & 1.44052 \\
& Kontrol & 22 & 76.8182 & 6.99412 & 1.49115 \\
\hline
\end{tabular}

(Sumber : Data Hasil Uji Independent Sample T-Test Hasil Belajar Aspek Psikomotorik, 2021)

Berdasarkan data hasil group statistics pada aspek psikomotorik dari kelas eksperimen sejumlah 23 peserta didik dan kelas kontrol sejumlah 22 peserta didik yang mengikuti tes praktik diperoleh rata-rata hasil belajar pada kelas eksperimen sebesar 85,00 sedangkan ratarata hasil belajar pada kelas kontrol sebesar 76,81. Nilai sig. (2-tailed) adalah 0,000<0,05 yang artinya terdapat perbedaan yang signifikan (nyata) rata-rata hasil belajar untuk ranah psikomotorik pada kelas eksperimen dan kelas kontrol.

Hal ini relevan dengan penelitian yang dilakukan oleh Winatha \& Abubakar (2018) dimana penelitian ini memperoleh hasil bahwa penggunaan E-modul dalam kegiatan pembelajaran dapat meningkatkan hasil belajar peserta didik. Hasil belajar pada penelitian ini ditunjukkan oleh perolehan rata-rata skor posttest lebih tinggi daripada rata-rata skor pretest.

\section{Simpulan}

Dari penelitian dan pengembangan ini menghasilkan E-modul berbasis Android pada mata pelajaran Administrasi Umum untuk semester genap kelas X OTKP. Aplikasi E-modul telah peneliti unggah di google drive agar dapat dimanfaatkan oleh pihak lain dengan link https://bit.ly/Emodul_AdministrasiUmum. 
E-modul berbasis Android yang dikembangkan telah diuji kelayakannya, berdasarkan uji validasi oleh ahli media memperoleh rata-rata keseluruhan skor sebesar 99,05\% dan pada uji validasi ahli materi memperoleh rata-rata keseluruhan skor sebesar $96,47 \%$ dapat dikatakan telah memenuhi kriteria sangat valid dan sangat efektif untuk digunakan sebagai sumber belajar peserta didik.

Pada uji coba kelompok besar di kelas eksperimen dan kelas kontrol terdapat perbedaan hasil belajar yang signifikan yang diperoleh oleh peserta didik. Hal ini didukung dengan perolehan analisis perhitungan nilai rata-rata hasil belajar pada kelas eksperimen lebih tinggi dari pada kelas kontrol. Pada aspek kognitif rata-rata skor hasil belajar yang diperoleh kelas eksperimen adalah sebesar 80,43 sedangkan pada kelas kontrol sebesar 72,27. Pada aspek psikomotorik rata-rata skor hasil belajar peserta didik lebih tinggi yaitu 85,00 sedangkan pada kelas psikomotorik sebesar 76,81.

\section{Ucapan Terima Kasih}

Penulis mengucapkan terimakasih kepada Universitas Negeri Malang dan SMK Muhammadiyah 3 Singosari yang telah memfasilitasi dan memberikan izin peneliti untuk melaksanakan kegiatan penelitian dan pengembangan ini.

\section{Daftar Rujukan}

Ahmar, A. S., \& Rahman, A. (2017). Development of teaching material using an Android. Global Journal of Engineering Education, 19(1), 72-76. https://doi.org/10.26858/gjeev19i1y2017p7376

Akbar, S. (2017). Instrumen Perangkat Pembelajaran. Bandung: PT Remaja Rosdakarya.

Arianti, A., \& Nugraha, J. (2019). Pengembangan Electronic Modul Berbasis Editor Eclipse Pada Kompetensi Dasar Memahami Teknologi Perkantoran, Otomatisasi Perkantoran, Dan Kantor Virtual Kelas X di SMK Negeri 1 Lamongan. Jurnal Pendidikan Administrasi Perkantoran (JPAP), 7 Nomor 03, 98-104.

Arsal, M., Danial, M., \& Hala, Y. (2019). Pengembangan Media Pembelajaran E-Modul Materi Sistem Peredaran Darah Pada Kelas XI MIPA SMAN 6 Barru The Development of E-Module Learning Media of Blood Circulatory System In Grade XI MIPA at SMAN 6 Barru. 434-442.

Daryanto. (2013). Menyusun Modul: Bahan Ajar Untuk Persiapan Pendidik Dalam Mengajar. Yogyakarta: Gava Media.

Fajriati, I. (2018). Pengembangan E-Modul Berbasis Lectora Inspire Mata Pelajaran Administrasi Humas dan Keprotokolan Pada Siswa Kelas XI APK di SMK PGRI 2 Sidoarjo. Jurnal Pendidikan Administrasi Perkantoran (JPAP), 6(3).

Fausih, M., \& Danang, T. (2015). Pengembangan Media E-Modul Mata Pelajaran Produktif Pokok Bahasan “Instalasi Jaringan Lan (Local Area Network)” Untuk Siswa Kelas Xi Jurusan Teknik Komputer Jaringan Di Smk Nengeri 1 Labang Bangkalan Madura. Jurnal UNESA, 01(01), 1-9. Retrieved from https://jurnalmahasiswa.unesa.ac.id/index.php/jmtp/article/view/10375

Fitriana, E. (2019). Pengembangan Media E-Modul Berbasis Aplikasi Android Materi Persamaan Dasar Akuntansi Mata Pelajaran Akuntansi Dasar Kelas X Akuntansi Di Smk Pgri 1 Tulungagung. Jurnal Mahasiswa Teknologi Pendidikan, 9(2).

Fitryani, H., \& Hunaepi. (2016). Pengemabangan Modul Elektronik Berbasis Smartphone Berplatform Android Pada Mata Kuliah Taksonomi Tumbuhan Tinggi. Jurnal Ilmiah Biologi "Bioscientist," 4(2), 97-106.

Gunadharma, A. (2011). Pengembangan Modul Elektronik Sebagai Sumber Belajar Untuk Mata Kuliah Multimedia Design.

Hamzah, I., \& Mentari, S. (2017). Development of Accounting E-Module to Support the Scientific Approach of Students Grade X Vocational High School. Journal of Accounting and Business Education, 2(1), 78. https://doi.org/10.26675/jabe.v1i1.9751 
Herawati, N. S., \& Muhtadi, A. (2018). Pengembangan modul elektronik (e-modul) interaktif pada mata pelajaran Kimia kelas XI SMA. Jurnal Inovasi Teknologi Pendidikan, 5(2), 180-191. https://doi.org/10.21831/jitp.v5i2.15424

Indonesia, U. U. R. (2003). Sistem pendidikan nasional. Jakarta: Direktorat Pendidikan Menengah Umum.

Ismiarti, D. R., \& Nikmah, C. (2021). Pengembangan E-Modul Otomatisasi Tata Kelola Kepegawaian Berbasis Android Pada Materi Semester Gasal Kelas XI OTKP 2 di SMK PGRI 2 Sidoarjo. Jurnal Pendidikan Administrasi Perkantoran (JPAP) 9, 28-38.

Krisnaresanti, A., Slamet, A., \& Wahyudin, A. (2018). E-Book Development of Trading Company Adjustment Journal Based on 2013 Curriculum. Journal of Economic Education, 7(1), 39-44.

Kurniati, A. T., Siswandari, \& Muchsini, B. (2018). Pengemabnagan E-Modul Exel Sebagai Upaya Peningkatan Motivasi Belajar Komputer Dasar Akuntansi Di SMK. Tata Arta: Jurnal Pendidikan Akuntansi, 4(2), 1018.

Laili, I., Ganefri, \& Usmeldi. (2019). Efektivitas Pengembangan E-Modul Project Based Learning Pada Mata Pelajaran Instalasi. Jurnal Ilmiah Pendidikan Dan Pembelajaran, 3, 306-315. Retrieved from https://ejournal.undiksha.ac.id/index.php/JIPP/article/download/21840/13513

Lestari, I. (2013). Pengembangan Bahan Ajar Berbasis Kompetensi. Akademia Permata.

Lestari, N. (2019). Development of Economic E-Module on Money and Banking Material For Student. Pionir, 1(Classroom Action Reasearch), 1-9. https://doi.org/10.17977/um013v3i22019p001

Martono, K. T., \& Nurhayati, O. D. (2014). Implementation of Android-Based Mobile Learning Application as a Flexible Learning Media. International Journal of Computer Science Issues, 11(3), 168-174.

Murtafi'ah, S. S. (2019). Pengembangan E-Modul Pembelajaran Pada Kompetensi Dasar Menerapkan Pembuatan Website Kelas Xi Bisnis Daring Dan Pemasaran Di Smk Negeri 1 Jombang. Jurnal Pendidikan Tata Niaga 07(02), 493-498.

Nurdiana, A. M., Sutarman, \& Widjianto. (2019). Pengembangan Media Modul Elektronik Berbasis Android pada Pokok Bahasan Suhu dan Kalor. Jurnal Riset Pendidikan Fisika, 2(1), 30-35.

Nurjayadi, M., \& Sadono, R. (2021). Development of e-module structure and protein function with flip PDF professional application through online learning Development of E-Module Structure and Protein Function with Flip PDF Professional Application through Online Learning. 040029(April).

Pendidikan, M. (2013).Peraturan Menteri Pendidikan dan Kebudayaan Republik Indonesia Nomor 70 Tahun 2013 tentang Kerangka Dasar dan Struktur Kurikulum Sekolah Menengah Kejuruan/Madrasah Aliyah Kejuruan. (2013). 1-234.

Purnamasari, A. W., Wiranatha, A. A. K. A. C., Made, N., \& Marini, I. (2016). Aplikasi M-Learning pada Platform Android. Merpati, 2(1), 167-178. https://doi.org/10.24843/JIM

Purwanto, D. (2011). Evaluasi Hasil Belajar. Yogyakarta: Pustaka Pelajar.

Raharjo, S. (2015). Cara Uji Independent Sample T-Test dan Interpretasi dengan SPSS.

Ricu Sidiq, \& Najuah. (2020). Pengembangan E-Modul Interaktif Berbasis Android pada Mata Kuliah Strategi Belajar Mengajar. Jurnal Pendidikan Sejarah, 9(1), 1-14. https://doi.org/10.21009/jps.091.01

Sanjaya, W. (2011). Perencanaan dan Desain Sistem Pembelajaran. Jakarta: Kencana Prenada Media Group.

Sjukur, S. B. (2012). Pengaruh blended learning terhadap motivasi belajar dan hasil belajar siswa di tingkat SMK. Jurnal Pendidikan Vokasi, 2(3), 368-378. https://doi.org/10.21831/jpv.v2i3.1043

Sugiyono. (2017). Metode Penelitian Pendidikan. Bandung: Alfabeta.

Suprianto, A., Ahmadi, F., \& Suminar, T. (2019). The Development of Mathematics Mobile Learning Media to Improve Students' Autonomous and Learning Outcomes. Journal of Primary Education, 8(1), 84-91. Retrieved from https://lens.org/161-652-040-912-402

Tania, L., \& Susilowibowo. (2017). Pengembangan Bahan Ajar E-Modul Sebagai Pendukung Pembelajaran Kurikulum 2013 Pada Materi Ayat Jurnal Penyesuaian Perusahaan Jasa Siswa Kelas X Akuntansi Smk Negeri 1 Surabaya. Jurnal Pendidikan Akuntansi (JPAK), 5(2), 1-9.

Uz, L. M. Z., Haryono, \& Wardani, S. (2019). The Development of Chemical E-Module Based on Problem of Learning to Improve The Concept of Student Understanding. Innovative Journal of Curriculum and Educational Technology, 8(2), 59-66. 
Jurnal Ekonomi, Bisnis dan Pendidikan, 1(6), 2021, 559-568

Wahyuni, P. S., Haryani, S., \& Jumaeri. (2020). Design of Integrated Corrosion E-module Vocational Context to Improve Critical Thinking Skills of Class X Students in Vocational High School. International Journal of Active Learning 5(2), 86-93.

Wijayanti, N. P. A., Damayanthi, L. P. E., Sunarya, I. M. G., \& Putrama, I. M. (2016). Pengembangan E-Modul Berbasis Project Based Learning Pada Mata Pelajaran Simulasi Digital Untuk Siswa Kelas X Studi Kasus Di Smk Negeri 2 Singaraja. Jurnal Pendidikan Teknologi Dan Kejuruan, 13(2), 184-197. https://doi.org/10.23887/jptk-undiksha.v13i2.8526

Wikipedia. (2019). Versi Android. Retrieved from https://id.wikipedia.org/wiki/Daftar_versi_Android

Winatha, K. R., \& Abubakar, M. M. (2018). The Usage Effectivity of Project-Based Interactive E-Module in Improving Students' Achievement. Jurnal Pendidikan Teknologi Dan Kejuruan, 24(2), 198-202. https://doi.org/10.21831/jptk.v24i2.20001

Wirawan, A. W., Indrawati, C. D. S., \& Rahmanto, A. N. (2017). Pengembangan Media Pembelajaran Kearsipan Digital Untuk Meningkatkan Hasil Belajar Siswa Smk Negeri 3 Surakarta. Jurnal Pendidikan Vokasi Februari, 7(2017), 78-86. Retrieved from http://journal.uny.ac.id/index.php/jpv

Zahid, M. Z. (2018). Aplikasi Berbasis Android untuk Pembelajaran: Potensi dan Metode Pengembangan. PRISMA. Prosiding Seminar Nasional Matematika, 1, 910-918. 